\title{
Endosomal $\mathrm{pH}$ in neuronal signaling and synaptic transmission: role of $\mathrm{Na}^{+} / \mathrm{H}^{+}$exchanger NHE5
}

\author{
Graham H. Diering ${ }^{1}$ and Masayuki Numata ${ }^{2 *}$ \\ 1 Department of Neuroscience, Johns Hopkins University School of Medicine, Baltimore, MD, USA \\ 2 Department of Biochemistry and Molecular Biology, University of British Columbia, Vancouver, BC, Canada
}

\section{Edited by:}

Ebbe Boedtkjer, Aarhus University,

Denmark

Reviewed by:

Enrique Soto, Universidad

Autónoma de Puebla, Mexico

Robert W. Putnam, Wright State

University Boonshoft School of

Medicine, USA

\section{*Correspondence:}

Masayuki Numata, Department of Biochemistry and Molecular Biology, University of British Columbia, 2350 Health Sciences Mall, Vancouver, BC V6T 1Z3, Canada

e-mail:mnumata@mail.ubc.ca
Neuronal precursor cells extend multiple neurites during development, one of which extends to form an axon whereas others develop into dendrites. Chemical stimulation of $\mathrm{N}$-methyl D-aspartate (NMDA) receptor in fully-differentiated neurons induces projection of dendritic spines, small spikes protruding from dendrites, thereby establishing another layer of polarity within the dendrite. Neuron-enriched $\mathrm{Na}^{+} / \mathrm{H}^{+}$exchanger NHE5 contributes to both neurite growth and dendritic spine formation. In resting neurons and neuro-endocrine cells, neuron-enriched NHE5 is predominantly associated with recycling endosomes where it colocalizes with nerve growth factor (NGF) receptor TrkA. NHE5 potently acidifies the lumen of TrkA-positive recycling endosomes and regulates cell-surface targeting of TrkA, whereas chemical stimulation of NMDA receptors rapidly recruits NHE5 to dendritic spines, alkalinizes dendrites and down-regulates the dendritic spine formation. Possible roles of NHE5 in neuronal signaling via proton movement in subcellular compartments are discussed.

Keywords: NMDA receptor, neurotrophins, Trk receptors, signaling endosomes, endocytic recycling, neurites, dendritic spines, protons

\section{INTRODUCTION}

A robust fluctuation in $\mathrm{pH}_{i}(\mathrm{pH}$ inside of the cell, or cytosolic $\mathrm{pH})$ and $\mathrm{pH}_{o}(\mathrm{pH}$ outside of the cell or extracellular $\mathrm{pH}$ ) greatly influence synaptic transmission, which is often associated with pathological conditions (Velisek, 1998; Hsu et al., 2000; Chesler, 2003). For example, seizure leads to interstitial acidification of hippocampal neurons (Somjen, 1984) and excessive acidosis inhibits synaptic transmission and eventually causes coma (Li and Siesjö, 1997), while alkalinization may induce seizures (Schuchmann et al., 2006). Conversely, strong synaptic stimulation initiates a series of changes in $\mathrm{pH}_{o}$ in the vicinity of the synapse beginning with an immediate acidification lasting a few milliseconds followed by a slower alkaline transient for several $100 \mathrm{~ms}$ (Chesler and Kaila, 1992). Epileptiform activity induced by low- $\mathrm{Mg}^{2+}$ was suppressed by acidic media (Velisek et al., 1994). While global changes in $\mathrm{pH}_{i}$ and $\mathrm{pH}_{o}$ may cause perilous effects on neuronal functions, transient (e.g., during neuronal development, in response to neuronal stimuli) and localized changes in $\mathrm{pH}$ in subcellular compartments (e.g., neuronal synapses and endosomal lumens) occur under non-pathological states and regulate neurological function.

Most of glutamate receptors including $\mathrm{N}$-methyl-D-aspartate (NMDA) receptors, $\alpha$-amino-3-hydroxy-5-methyl-4isoxazolepropionic acid (AMPA) receptors (Ihle and Patneau, 2000), Kainate receptors (Mott et al., 2003), and the group III metabotropic glutamate receptors (Levinthal et al., 2009) are down-regulated by extracellular protons. Among them, NMDA receptors are particularly sensitive to extracellular protons because of the physiological $\mathrm{pK}_{a}$ of 7.3-7.5 (Tang et al., 1990; Traynelis and Cull-Candy, 1990; Banke et al., 2005). Given the importance of NMDA receptors for synaptic plasticity, this suggests that local $\mathrm{pH}$ in the vicinity of the synapse may be important for the induction and maintenance of long-term potentiation (LTP) and long-term depression (LTD). Consistent with this notion, high-frequency stimulation of axon projections from the hippocampus CA3 region, termed Schaffer collaterals, failed to induce LTP in hippocampal CA1 pyramidal neurons when the cells were bathed in an acidified media, likely a result of NMDA receptor inhibition (Velisek, 1998). $\mathrm{pH}_{o}$ changes at the confined space of synaptic cleft may coordinate synaptic excitability by synergistically regulating excitatory and inhibitory receptors of post-synaptic neurons in a reciprocal manner. The best-studied $\mathrm{pH}_{o}$-sensitive ion translocating mechanism would be $A$ cid $\underline{S}$ ensing $\underline{I}$ on $\underline{C}$ hannels (ASICs), proton-gated ion channels predominantly expressed in the nervous system, which are involved in pain, seizure, stroke and anxiety-related neurological disorders (Wemmie et al., 2008; Gründer and Chen, 2010; Zha, 2013). Acidic $\mathrm{pH}_{o}$ facilitates the chloride conductance of certain gamma amino butyric acid (GABA) receptors, which inhibits firing of action potentials (Krishek et al., 1996; Dietrich and Morad, 2010). It has been also suggested that the pre-synaptic $\mathrm{K}^{+}$-current is regulated by $\mathrm{pH}_{o}$ (Almanza et al., 2008).

Endosomes are membrane-bound orgaenelles that internalize membrane components and external molecules. Internalized vesicles are delivered to lysosomes for degradation or return to the plasma membrane via endocytic recycling pathways (Maxfield and Mcgraw, 2004). The endosomal lumen is acidic (Casey et al., 2010; Scott and Gruenberg, 2011), which is established by Vacuolar proton-translocating ATPases (V-ATPases) and the counter-ion conductance by anion channels/transporters such as the $\mathrm{Cl}^{-}$channel and $\mathrm{Cl}^{-} / \mathrm{H}^{+}$exchanger $\mathrm{ClC}$ family (Forgac, 2007; Stauber and Jentsch, 2013). Anion channels/transporters relieve 
the charge-imbalance by pumping anions into the lumen and facilitate continuous action of V-ATPases to pump protons to the lumen. In neurons and neuroendocrine cells, the neuronenriched $\mathrm{Na}^{+} / \mathrm{H}^{+}$exchanger NHE5 seems to play an equally important role as V-ATPases. A unique aspect of NHE5 is that it acts in both endosomes and synapses. We discuss the potential role of proton concentration oscillations by NHE5 in neuronal signaling.

\section{$\mathrm{Na}^{+} / \mathrm{H}^{+}$EXCHANGERS IN NEURONS}

$\underline{\mathrm{Na}}^{+} / \underline{H}^{+}$exchangers (NHEs) are a group of secondary active antiporters that typically exchange extracellular $\mathrm{Na}^{+}$for cytosolic protons in a 1:1 ratio, thereby regulating cellular $\mathrm{pH}$ and cell volume (Aronson, 1985; Wakabayashi et al., 1997; Orlowski and Grinstein, 2004; Slepkov et al., 2007). The recovery from acute acidification in biochemically-isolated synapses requires external $\mathrm{Na}^{+}$whereas $\mathrm{HCO}_{3}^{-}$deprivation or inhibitors against bicarbonate transporters also affect $\mathrm{pH}_{i}$ of some neurons (Sauvaigo et al., 1984; Nachshen and Drapeau, 1988; Chesler, 2003). Although $\mathrm{Na}^{+}$-driven $\mathrm{Cl}^{-}-\mathrm{HCO}_{3}^{-}$exchange activity was detected in freshly dissociated hippocampal neurons (Schwiening and Boron, 1994) and some neuronal cell populations may require bicarbonatedependent $\mathrm{pH}$ regulation mechanisms, $\mathrm{Na}^{+}$-dependent recovery from acute cytosolic acidification occurs even in bicarbonatefree media (Raley-Susman et al., 1991). Thus, NHEs play crucial roles in $\mathrm{pH}$ regulation in neurons while $\mathrm{HCO}_{3}^{-}$is also likely an important $\mathrm{pH}$ regulator of certain types of neurons. NHEactivity indeed regulates synaptic transmission at glutamatergic, GABAergic and dopaminergic synapses (Trudeau et al., 1999; Jang et al., 2006; Rocha et al., 2008; Dietrich and Morad, 2010) and there is evidence suggesting that local $\mathrm{pH}$ contributes to the induction and maintenance of LTP (Velisek, 1998; Ronicke et al., 2009; Diering et al., 2011). In mammals, nine NHE isoforms NHE1-NHE9 have been characterized as secondary active ion transporters (Brett et al., 2005; Donowitz et al., 2013). NHE1-NHE5 are functionally well-defined NHEs that exhibit the typical $\mathrm{Na}^{+}-\mathrm{H}^{+}$exchange activity, of which ubiquitously expressed NHE1 and neuron-enriched NHE5 are the two predominant isoforms in the brain (Attaphitaya et al., 1999; Baird et al., 1999). NHE6-NHE9 exhibit “atypical” cation non-specific organellar activity across acidic organellar membranes (Orlowski and Grinstein, 2007; Ohgaki et al., 2011) therefore referred to as CNO-NHEs. Since CNO-NHEs have a higher affinity to $\mathrm{K}^{+}$than $\mathrm{Na}^{+}$, their physiological mode of action is likely to "leak" protons from the lumen of acidic organelles driven by the influx of $\mathrm{K}^{+}$, the major cytosolic monovalent cation. The unique cationnonspecific antiporter activity was reported first in NHE7 in a heterologous expression system (Numata and Orlowski, 2001) and a similar activity was subsequently detected in other CNONHEs in an in vitro reconstitution system (Nakamura et al., 2005). More recent studies showed that genetic depletion of NHE6 leads to endosomal acidification (Ohgaki et al., 2010; Xinhan et al., 2011; Ouyang et al., 2013) in neuronal and nonneuronal cells, supporting the physiological relevance of $\mathrm{CNO}$ NHEs for proton-leak from acidic organelles. Although widely expressed in most mammalian cell types, genetic alterations in NHE6, NHE7, and NHE9 have been associated with X-linked mental retardation syndrome (Gilfillan et al., 2008; Schroer et al., 2010; Takahashi et al., 2011; Mignot et al., 2013), late-onset Alzheimer's disease (Meda et al., 2012), and autism spectrum disorders and attention-deficit/hyperactivity spectrum disorder (ADHD) (Lasky-Su et al., 2008; Morrow et al., 2008; Markunas et al., 2010; Mick et al., 2010), respectively.

NHE1 null-mice exhibit neurological phenotypes including epileptic-like seizures resulting from enhanced neuronal excitability and loss of Purkinje cells in cerebellum (Cox et al., 1997; Liu et al., 2013), but otherwise brain development occurs without major complications. This suggests that while selected neurons such as Purkinje cells are particularly sensitive to $\mathrm{pH}$ changes, other neurons possess distinct mechanisms to defend against a $\mathrm{pH}$ challenge. Unique NHE-activity distinct from NHE1 has been detected in hippocampal neurons, which is relatively insensitive to amiloride, highly sensitive to ATP-depletion and has a high affinity to $\mathrm{Li}^{+}$(Raley-Susman et al., 1991; Schwiening and Boron, 1994; Baxter and Church, 1996). NHE5 is 100fold more resistant to amiloride than NHE1 (Masereel et al., 2003) and has a higher affinity to $\mathrm{Li}^{+}$than NHE1 (Szabo et al., 2000). Moreover, ATP-depletion almost completely abolishes NHE5 activity (Szabo et al., 2000) whereas NHE1 is only partially suppressed by ATP-depletion (Kapus et al., 1994). Thus, NHE5 is most likely the responsible molecule for non-NHE1 type NHE activity physiologically detected in hippocampal neurons. The highly ATP-sensitive nature implies a possible role of NHE5 in pathological processes such as ischemia and reperfusion. While NHE5 is predominantly associated with recycling endosomes and potently acidifies the lumen in resting neuroendocrine model cells (Diering et al., 2013), it is acutely targeted to dendritic spines upon neuronal activation [(Diering et al., 2011) and see below]. Movement of protons from the cytosol to the endosomal lumen via NHE5 should theoretically affect the global cytosolic $\mathrm{pH}\left(\mathrm{pH}_{i}\right)$, however this depends on a number of other factors including the volume of recycling endosomes and the buffering power, and the actual effect of NHE5 on the overall cytosolic $\mathrm{pH}$ is not clear. Currently NHE5 knockout mice are not available. In summary, currently available data suggest that ubiquitous $\mathrm{Na}^{+} / \mathrm{H}^{+}$exchanger NHE1, neuron-enriched NHE5 and CNONHEs across organellar membranes are the three major NHEs in neurons.

\section{LOCAL pH MODULATES DENDRITIC SPINE MORPHOLOGY}

Most forms of LTP require activation of synaptic NMDA receptors (NMDARs) (Malenka and Bear, 2004) and subsequent calcium influx. This initiates a signaling program that eventually recruits AMPA receptor to synapses (Shepherd and Huganir, 2007) and facilitates the formation of dendritic spines (Engert and Bonhoeffer, 1999; Maletic-Savatic et al., 1999; Lang et al., 2004; Matsuzaki et al., 2004). NMDARs have especially high proton sensitivity with a $\mathrm{pK}_{a}$ of 7.3-7.5 (Tang et al., 1990; Traynelis and Cull-Candy, 1990) due to a discrete extracellular proton binding site distinct from other ligand binding sites (Banke et al., 2005). The proton binding site is associated with the channel gating mechanism such that channel open probability is strongly suppressed by proton binding. Unlike the voltage-dependent block of NMDARs by $\mathrm{Mg}^{2+}$ ions (Nowak et al., 1984; Kumamoto, 
1996), this proton block is not dependent on voltage. Thus, at resting extracellular $\mathrm{pH}$ close to 7.3, a tonic proton block exists, which maintains NMDAR-activity to about $50 \%$, which means that any slight deviation in local $\mathrm{pH}$ should theoretically have a profound impact on synaptic transmission and synaptic plasticity. Therefore, synaptic $\mathrm{pH}$-regulating ion transporters like NHE5 may contribute to a $\mathrm{pH}$-based inhibitory tone to limit synaptic transmission and synaptic plasticity.

Under basal conditions, NHE5 is predominantly localized to recycling endosomes. Within minutes following NMDAR activation by co-agonist glycine, NHE5 is recruited into dendritic spines and exposed onto the cell surface at excitatory synapses. Stimulation of NMDARs by glycine is often referred to as "chemical LTP" because this manipulation induces longlasting mEPSC, which is mediated by AMPA receptor components $\left(\mathrm{mEPSC}_{\mathrm{AMPA}}\right)$ and is inhibited by NMDAR inhibitors ( $\mathrm{Lu}$ et al., 2001). Dendritic spines then undergo an NHE5-dependent alkaline shift in their $\mathrm{pH}_{i}$ as NHE5 transports cytosolic protons into the extracellular space (Diering et al., 2011). A model is proposed in which NHE5 targeted to dendritic spines by NMDAR-activation acutely mobilizes protons across the postsynaptic membrane, which in turn down-regulates NMDAR, thereby forming a negative-feedback loop (Figure 1). As neurological disorders such as depression, schizophrenia and autism are associated with aberrant NMDAR activity and dendritic spine morphogenesis (Lakhan et al., 2013; Zhou and Sheng, 2013), it is tempting to speculate that NHE5 may be involved in pathogenic processes of these diseases. Recently, Deane and colleagues reported that chemical LTP enhances translocation of NHE6 to dendrites in mouse hippocampal neurons (Deane et al., 2013), resembling the targeting behavior of NHE5 in rat hippocampal neurons (Diering et al., 2011). Small populations of CNO-NHEs are indeed targeted to the plasma membrane in non-neuronal cells (Lin et al., 2007; Kagami et al., 2008; Ohgaki et al., 2008; Onishi et al., 2012) and in vestibular hair cells (Hill et al., 2006); however, whether CNO-NHEs transiently delivered to the plasma membrane exhibit $\left(\mathrm{Na}^{+}\right.$, $\left.\mathrm{K}^{+}\right) / \mathrm{H}^{+}$exchange activity remains to be determined. Another important unanswered question is whether NHE6 participates in activity-dependent $\mathrm{pH}$ regulation of dendritic spines. Future investigations are needed to address these important mechanistic questions. Curiously, acid-sensing ion channel ASIC1a is present in dendritic spines, serves as a $\mathrm{pH}$-sensor and influences the density of spines (Zha et al., 2006), raising an interesting possibility that ASIC1 in dendritic spines may be regulated by NHE5 and possibly NHE6.

\section{ENDOSOMAL ACIDITY IN TRK TARGETING AND SIGNALING}

Binding of neurotrophins [e.g., nerve growth factor (NGF), brain-derived neurotrophic factor (BDNF) and neurotrophin-3] to their high affinity TrkA, TrkB and TrkC stimulates downstream signaling, leading to neuronal differentiation and survival (Huang and Reichardt, 2001; Chao, 2003). Vectorial targeting of the NGFreceptor TrkA from the endosomal pool to growing neurite tips serves as a regulatory mechanism for neurotrophin signaling (Arimura et al., 2009; Vaegter et al., 2011) and neurite outgrowth

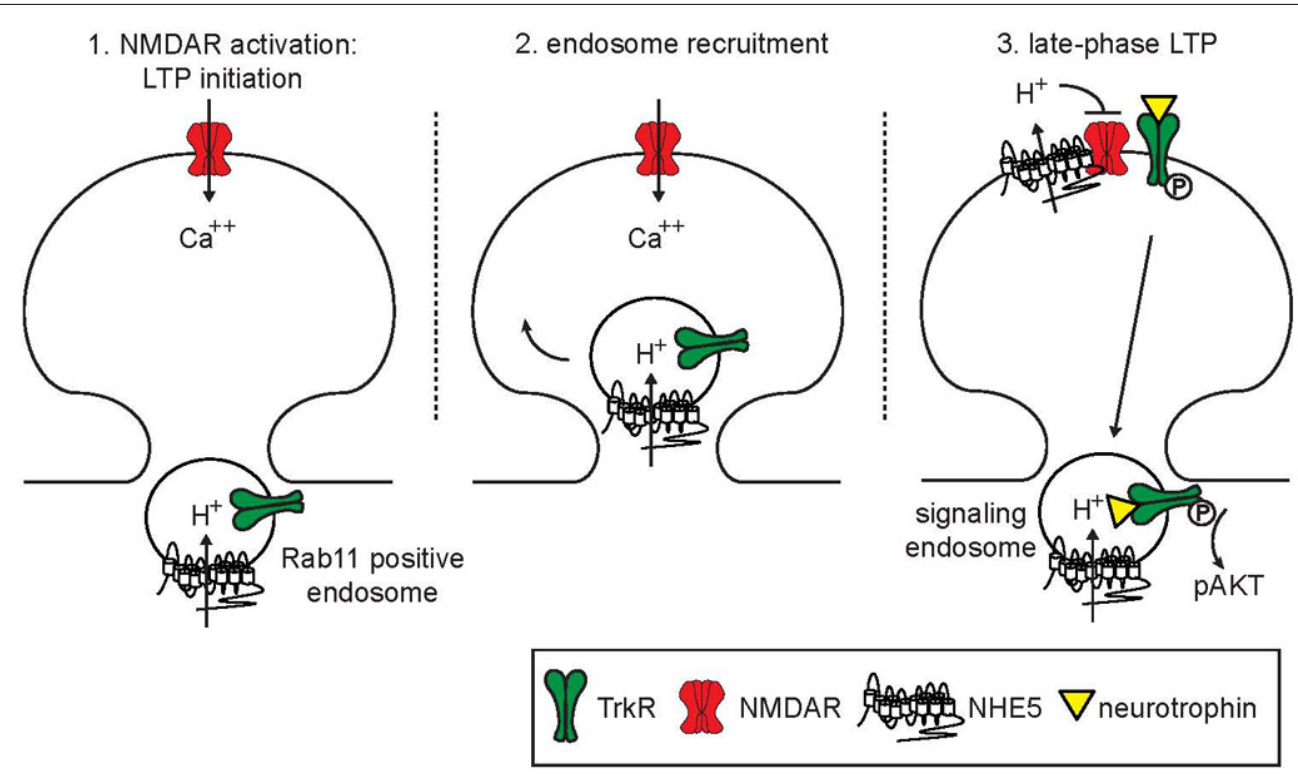

FIGURE 1 | Model of endosomal and synaptic functions of NHE5. At steady state, NHE5 is primarily associated with recycling endosomes, where it acts to acidify the lumen of this compartment. Upon activation of NMDA receptors, recycling endosomes containing NHE5 and Trk receptors are mobilized and recruited to active synapses. One possibility is that signaling downstream of NMDA receptors acutely stimulates NHE5 activity in the endosomal membrane, driving endosomal acidification and promoting endosomal recycling. Following insertion,
NHE5 is active on plasma membrane, acting to supress further NMDA receptor activity through localized acidification of the synaptic cleft. In addition, active NHE5 can support the surface expression of Trk receptors and enhance AKT signaling from recycling endosomes. These coordinated activities may help the synapse transition from an initiation phase of LTP into a consolidation phase, limiting excitotoxicity from sustained NMDA receptor activation while promoting synapse strengthening through local neurotrophin signaling. 
(Ascano et al., 2009). Similarly, endocytic recycling recruits TrkB to the post-synaptic density during LTP that is required for dendritic branching (Huang et al., 2013; Lazo et al., 2013). Thus, endocytic recycling not only regulates the cell-surface availability of Trk proteins but also provides the accurate targeting path to neurites.

Rat pheochromocytoma PC12 cells, widely used as a neuroendocrine model (Greene and Tischler, 1976), have more acidic recycling endosomal $\mathrm{pH}$ of $\sim 6.2$ (Diering et al., 2013) than recycling endosomal $\mathrm{pH}$ of $\sim 6.5$ in fibroblasts (Maxfield and Mcgraw, 2004; Scott and Gruenberg, 2011). NHE5-depletion by shRNA or V-ATPase-inhibition by Bafilomycin lead to a similar degree of alkalinization of recycling endosomes to $\mathrm{pH}=\sim 6.5$ in PC12 cells, whereas concomitant inhibition of NHE5 and VATPase further alkalinizes recycling endosomes to $\mathrm{pH}=\sim 6.75$. These results indicate that NHE5 acidifies recycling endosomes as potently as V-ATPases in PC12 cells. NHE5 and TrkA colocalize intracellularly by double immunofluorescence microscopy and NHE5-depletion reduces cell-surface targeting of TrkA, and impairs NGF-induced neurite formation; while V-ATPase inhibitor Bafilomycin has also decreased the cell-surface population of TrkA (Diering et al., 2013). Importantly, NHE5 depletion as well as V-ATPase inhibition has impaired endocytic recycling of TrkA but not transferrin receptor (TfnR) or $\mathrm{Na}^{+} / \mathrm{K}^{+}$-ATPase. These results suggest that endosomal acidification is important in the polarized targeting of specific endosomal cargoes in PC12 cells. It was recently reported that NHE6 deletion impairs neurotrophin signaling and affects axonal and dendritic branching of hippocampal neurons (Ouyang et al., 2013). Genetic depletion leads to excessive acidification of late endo-lysosomes and facilitates degradation of $\operatorname{TrkB}$, which in turn decreases responsiveness to BDNF. However, a significant population of NHE6 seems to be associated with recycling endosomes and other yetto-be identified intracellular compartments (Ouyang et al., 2013). NHE6 depletion was shown to acidify recycling endosomal $\mathrm{pH}$ in HeLa cells (Xinhan et al., 2011) and hepatocytes (Ohgaki et al., 2010), and NHE6 in hepatocytes affects polarized distribution of membrane lipids to the apical surface. Taken together, it is possible that NHE6 in neurons regulates endocytic recycling of TrkB. We suggest that the balanced action of NHE5, NHE6 and perhaps other CNO-NHEs in different organelles along the endocytic and recycling pathway is needed for proper targeting of Trk proteins, and impairment of any of their function may affect neurotrophin signaling.

Although both phosphatidylinositol 3-kinase (PI3K)-Akt and extracellular signal-regulated kinase (Erk) signaling pathways are downstream of NGF-TrkA, PI3K-Akt signaling seems to be more severely affected by luminal alkalinization, suggesting that endosomal $\mathrm{pH}$ may directly influence PI3K-Akt signaling in addition to its role in TrkA targeting. Indeed, Akt signaling occurs in endosomes in various cell types (Garcia-Regalado et al., 2008; Schenck et al., 2008; Walz et al., 2010; Nazarewicz et al., 2011) including NGF-treated PC12 cells (Lin et al., 2006; Varsano et al., 2006). Endosomes provide a confined space that allows for continuous signaling from the internalized ligand-receptor complex (Gould and Lippincott-Schwartz, 2009; Murphy et al., 2009; Platta and Stenmark, 2011) and certain signaling may arise in endosomes
(Sorkin and von Zastrow, 2009; Scita and Di Fiore, 2010). Thus, although the plasma membrane is undoubtedly the most important cellular location for the initial activation of PI3K-Akt signaling, sustained signaling does occur in endosomes where $\mathrm{pH}$ may modulate the signaling intensity.

Trk neurotrophin receptors are likely associated with diverse endosomal populations. Aside from the recycling endosomal (Diering et al., 2013) and late endosomal pH (Ouyang et al., 2013), early endosomal $\mathrm{pH}$ has been suggested to influence neurotrophin signaling by modulating the neurotrophin-receptor binding and cell-surface targeting that is mediated by a small GTPase Racl and coffilins (Harrington et al., 2011). As such, it is possible that non-selective perturbation of all the acidic compartments by Bafilomycin or weak alkaline agents may lead to mixed biological effects. In future studies, it will be important to dissect the precise role of $\mathrm{pH}$ in different organellar compartments in neurotrophin signaling.

\section{CONCLUDING REMARIS}

Compelling experimental evidence suggests that synaptic functions are tightly controlled by endocytic recycling (Park et al., 2006; Wang et al., 2008). While the importance of $\mathrm{pH}$ in localized electrical activity, cell signaling and vesicular trafficking is well recognized, the molecular basis underlying compartmentalized $\mathrm{pH}$ regulation in neurons has been lacking. We now suggest that the recycling plasma membrane type NHE5 in neuroendocrine and neuronal cells potently acidifies recycling endosomes and modulates signaling events occurring in endosomes and synapses. Though still in its early stage, NHE5 offers an example of how localized $\mathrm{pH}$ regulation can impact synaptic plasticity and neuronal differentiation.

\section{ACKNOWLEDGMENTS}

This study has been supported by the Natural Sciences and Engineering Research Council of Canada (NSERC). Graham H. Diering is a Canadian Institutes of Health Research (CIHR) postdoctoral scholar. We thank Dr. Sarah Cohen (NIH) and Dr. Yuka Numata (UBC) for their critical reading of the manuscript.

\section{REFERENCES}

Almanza, A., Mercado, F., Vega, R., and Soto, E. (2008). Extracellular pH modulates the voltage-dependent $\mathrm{Ca}^{2+}$ current and low threshold $\mathrm{K}^{+}$current in hair cells. Neurochem. Res. 33, 1435-1441. doi: 10.1007/s11064-007-9565-9

Arimura, N., Kimura, T., Nakamuta, S., Taya, S., Funahashi, Y., Hattori, A., et al. (2009). Anterograde transport of TrkB in axons is mediated by direct interaction with Slp1 and Rab27. Dev. Cell 16, 675-686. doi: 10.1016/j.devcel.2009.03.005

Aronson, P. S. (1985). Kinetic properties of the plasma membrane $\mathrm{Na}^{+}-\mathrm{H}^{+}$exchanger. Annu. Rev. Physiol. 47, 545-560. doi: 10.1146/annurev.ph.47.030185.002553

Ascano, M., Richmond, A., Borden, P., and Kuruvilla, R. (2009). Axonal targeting of Trk receptors via transcytosis regulates sensitivity to neurotrophin responses. J. Neurosci. 29, 11674-11685. doi: 10.1523/JNEUROSCI.1542-09.2009

Attaphitaya, S., Park, K., and Melvin, J. E. (1999). Molecular cloning and functional expression of a rat $\mathrm{Na}^{+} / \mathrm{H}^{+}$exchanger (NHE5) highly expressed in brain. J. Biol. Chem. 274, 4383-4388. doi: 10.1074/jbc.274.7.4383

Baird, N. R., Orlowski, J., Szabo, E. Z., Zaun, H. C., Schultheis, P. J., Menon, A. G., et al. (1999). Molecular cloning, genomic organization, and functional expression of $\mathrm{Na}^{+} / \mathrm{H}^{+}$exchanger isoform 5 (NHE5) from human brain. J. Biol. Chem. 274, 4377-4382. doi: 10.1074/jbc. 274.7.4377 
Banke, T. G., Dravid, S. M., and Traynelis, S. F. (2005). Protons trap NR1/NR2B NMDA receptors in a nonconducting state. J. Neurosci. 25, 42-51. doi: 10.1523/JNEUROSCI.3154-04.2005

Baxter, K. A., and Church, J. (1996). Characterization of acid extrusion mechanisms in cultured fetal rat hippocampal neurones. J. Physiol. 493 (pt 2), 457-470.

Brett, C. L., Donowitz, M., and Rao, R. (2005). Evolutionary origins of eukaryotic sodium/proton exchangers. Am. J. Physiol. Cell Physiol. 288, C223-C239. doi: 10.1152/ajpcell.00360.2004

Casey, J. R., Grinstein, S., and Orlowski, J. (2010). Sensors and regulators of intracellular pH. Nat. Rev. Mol. Cell Biol. 11, 50-61. doi: 10.1038/nrm2820

Chao, M. V. (2003). Neurotrophins and their receptors: a convergence point for many signalling pathways. Nat. Rev. Neurosci. 4, 299-309. doi: 10.1038/nrn1078

Chesler, M. (2003). Regulation and modulation of pH in the brain. Physiol. Rev. 83, 1183-1221. doi: 10.1152/physrev.00010.2003

Chesler, M., and Kaila, K. (1992). Modulation of $\mathrm{pH}$ by neuronal activity. Trends Neurosci. 15, 396-402. doi: 10.1016/0166-2236(92)90191-A

Cox, G. A., Lutz, C. M., Yang, C. L., Biemesderfer, D., Bronson, R. T., Fu, A., et al. (1997). Sodium/hydrogen exchanger gene defect in slow-wave epilepsy mutant mice. Cell 91, 139-148. doi: 10.1016/S0092-8674(01)80016-7

Deane, E. C., Ilie, A. E., Sizdahkhani, S., Das Gupta, M., Orlowski, J., and Mckinney, R. A. (2013). Enhanced recruitment of endosomal $\mathrm{Na}^{+} / \mathrm{H}^{+}$Exchanger NHE6 into dendritic spines of hippocampal pyramidal neurons during NMDA receptor-dependent long-term potentiation. J. Neurosci. 33, 595-610. doi: 10.1523/JNEUROSCI.2583-12.2013

Diering, G. H., Mills, F., Bamji, S. X., and Numata, M. (2011). Regulation of dendritic spine growth through activity-dependent recruitment of the brain-enriched $\mathrm{Na}^{+} / \mathrm{H}^{+}$exchanger NHE5. Mol. Biol. Cell 22, 2246-2257. doi: 10.1091/mbc.E11-01-0066

Diering, G. H., Numata, Y., Fan, S., Church, J., and Numata, M. (2013). Endosomal acidification by $\mathrm{Na}^{+} / \mathrm{H}^{+}$exchanger NHE5 regulates TrkA cell-surface targeting and NGF-induced PI3K signaling. Mol. Biol. Cell 24, 3435-3448. doi: 10.1091/mbc.E12-06-0445

Dietrich, C. J., and Morad, M. (2010). Synaptic acidification enhances GABAA signaling. J. Neurosci. 30, 16044-16052. doi: 10.1523/JNEUROSCI.6364-09.2010

Donowitz, M., Ming Tse, C., and Fuster, D. (2013). SLC9/NHE gene family, a plasma membrane and organellar family of $\mathrm{Na}^{+} / \mathrm{H}^{+}$exchangers. Mol. Asp. Med. 34, 236-251. doi: 10.1016/j.mam.2012.05.001

Engert, F., and Bonhoeffer, T. (1999). Dendritic spine changes associated with hippocampal long-term synaptic plasticity. Nature 399, 66-70. doi: 10.1038/19978

Forgac, M. (2007). Vacuolar ATPases: rotary proton pumps in physiology and pathophysiology. Nat. Rev. Mol. Cell Biol. 8, 917-929. doi: 10.1038/nrm2272

Garcia-Regalado, A., Guzman-Hernandez, M. L., Ramirez-Rangel, I., RoblesMolina, E., Balla, T., Vazquez-Prado, J., et al. (2008). G protein-coupled receptor-promoted trafficking of Gbetalgamma2 leads to AKT activation at endosomes via a mechanism mediated by Gbetalgamma2-Rab11a interaction. Mol. Biol. Cell 19, 4188-4200. doi: 10.1091/mbc.E07-10-1089

Gilfillan, G. D., Selmer, K. K., Roxrud, I., Smith, R., Kyllerman, M., Eiklid, K., et al. (2008). SLC9A6 mutations cause X-linked mental retardation, microcephaly, epilepsy, and ataxia, a phenotype mimicking Angelman syndrome. Am. J. Hum. Genet. 82, 1003-1010. doi: 10.1016/j.ajhg.2008.01.013

Gould, G. W., and Lippincott-Schwartz, J. (2009). New roles for endosomes: from vesicular carriers to multi-purpose platforms. Nat. Rev. Mol. Cell Biol. 10, 287-292. doi: 10.1038/nrm2652

Greene, L. A., and Tischler, A. S. (1976). Establishment of a noradrenergic clonal line of rat adrenal pheochromocytoma cells which respond to nerve growth factor. Proc. Natl. Acad. Sci. U.S.A. 73, 2424-2428. doi: 10.1073/pnas.73.7.2424

Gründer, S., and Chen, X. (2010). Structure, function, and pharmacology of acidsensing ion channels (ASICs): focus on ASICla. Int. J. Physiol. Pathophysiol. Pharmacol. 2, 73.

Harrington, A. W., St Hillaire, C., Zweifel, L. S., Glebova, N. O., Philippidou, P., Halegoua, S., et al. (2011). Recruitment of actin modifiers to TrkA endosomes governs retrograde NGF signaling and survival. Cell 146, 421-434. doi: 10.1016/j.cell.2011.07.008

Hill, J. K., Brett, C. L., Chyou, A., Kallay, L. M., Sakaguchi, M., Rao, R., et al. (2006). Vestibular hair bundles control $\mathrm{pH}$ with $\left(\mathrm{Na}^{+}, \mathrm{K}^{+}\right) / \mathrm{H}^{+}$exchangers NHE6 and NHE9. J. Neurosci. 26, 9944-9955. doi: 10.1523/JNEUROSCI.2990-06.2006

Hsu, K. S., Liang, Y. C., and Huang, C. C. (2000). Influence of an extracellular acidosis on excitatory synaptic transmission and long-term potentiation in the CA1 region of rat hippocampal slices. J. Neurosci. Res. 62, 403-415. doi: 10.1002/1097-4547(20001101)62:3<403::AID-JNR11>3.0.CO;2-3

Huang, E. J., and Reichardt, L. F. (2001). Neurotrophins: roles in neuronal development and function. Annu. Rev. Neurosci. 24, 677-736. doi: 10.1146/annurev.neuro.24.1.677

Huang, S.-H., Wang, J., Sui, W.-H., Chen, B., Zhang, X.-Y., Yan, J., et al. (2013). BDNF-dependent recycling facilitates TrkB translocation to postsynaptic density during LTP via a Rab11-Dependent pathway. J. Neurosci. 33, 9214-9230. doi: 10.1523/JNEUROSCI.3256-12.2013

Ihle, E. C., and Patneau, D. K. (2000). Modulation of alpha-amino-3-hydroxy5-methyl-4-isoxazolepropionic acid receptor desensitization by extracellular protons. Mol. Pharmacol. 58, 1204-1212.

Jang, I. S., Brodwick, M. S., Wang, Z. M., Jeong, H. J., Choi, B. J., and Akaike, N. (2006). The $\mathrm{Na}^{+} / \mathrm{H}^{+}$exchanger is a major $\mathrm{pH}$ regulator in GABAergic presynaptic nerve terminals synapsing onto rat CA3 pyramidal neurons. J. Neurochem. 99, 1224-1236. doi: 10.1111/j.1471-4159.2006.04168.x

Kagami, T., Chen, S., Memar, P., Choi, M., Foster, L. J., and Numata, M. (2008). Identification and biochemical characterization of the SLC9A7 interactome. Mol. Membr. Biol. 25, 436-447. doi: 10.1080/09687680802263046

Kapus, A., Grinstein, S., Wasan, S., Kandasamy, R., and Orlowski, J. (1994). Functional characterization of three isoforms of the $\mathrm{Na}^{+} / \mathrm{H}^{+}$exchanger stably expressed in Chinese hamster ovary cells. ATP dependence, osmotic sensitivity, and role in cell proliferation. J. Biol. Chem. 269, 23544-23552.

Krishek, B. J., Amato, A., Connolly, C. N., Moss, S. J., and Smart, T. G. (1996). Proton sensitivity of the $\operatorname{GABA}(\mathrm{A})$ receptor is associated with the receptor subunit composition. J. Physiol. 492 (pt 2), 431-443.

Kumamoto, E. (1996). Neuromodulation by $\mathrm{Mg}^{2+}$ and polyamines of excitatory amino acid currents in rodent neurones in culture. Magnes. Res. 9, 317-327.

Lakhan, S. E., Caro, M., and Hadzimichalis, N. (2013). NMDA receptor activity in neuropsychiatric disorders. Front. Psychiatry 4:52. doi: 10.3389/fpsyt.2013.00052

Lang, C., Barco, A., Zablow, L., Kandel, E. R., Siegelbaum, S. A., and Zakharenko, S. S. (2004). Transient expansion of synaptically connected dendritic spines upon induction of hippocampal long-term potentiation. Proc. Natl. Acad. Sci. U.S.A. 101, 16665-16670. doi: 10.1073/pnas.0407581101

Lasky-Su, J., Anney, R. J., Neale, B. M., Franke, B., Zhou, K., Maller, J. B., et al. (2008). Genome-wide association scan of the time to onset of attention deficit hyperactivity disorder. Am. J. Med. Genet. B Neuropsychiatr. Genet. 147B, 1355-1358. doi: 10.1002/ajmg.b.30869

Lazo, O. M., Gonzalez, A. S., Ascano, M., Kuruvilla, R., Couve, A. S., and Bronfman, F. C. (2013). BDNF regulates Rab11-Mediated recycling endosome dynamics to induce dendritic branching. J. Neurosci. 33, 6112-6122. doi: 10.1523/JNEUROSCI.4630-12.2013

Levinthal, C., Barkdull, L., Jacobson, P., Storjohann, L., van Wagenen, B. C., Stormann, T. M., et al. (2009). Modulation of group III metabotropic glutamate receptors by hydrogen ions. Pharmacology 83, 88-94. doi: 10.1159/000180124

Li, P.-A., and Siesjö, B. K. (1997). Role of hyperglycaemia-related acidosis in ischaemic brain damage. Acta Physiologica Scandinavica 161, 567-580. doi: 10.1046/j.1365-201X.1997.00264.x

Lin, D. C., Quevedo, C., Brewer, N. E., Bell, A., Testa, J. R., Grimes, M. L., et al. (2006). APPL1 associates with TrkA and GIPC1 and is required for nerve growth factor-mediated signal transduction. Mol. Cell. Biol. 26, 8928-8941. doi: 10.1128/MCB.00228-06

Lin, P. J., Williams, W. P., Kobiljski, J., and Numata, M. (2007). Caveolins bind to $\left(\mathrm{Na}^{+}, \mathrm{K}^{+}\right) / \mathrm{H}^{+}$exchanger NHE7 by a novel binding module. Cell Signal. 19, 978-988. doi: 10.1016/j.cellsig.2006.11.006

Liu, Y., Zaun, H. C., Orlowski, J., and Ackerman, S. L. (2013). CHP1-Mediated NHE1 biosynthetic maturation is required for purkinje cell axon homeostasis. J. Neurosci. 33, 12656-12669. doi: 10.1523/JNEUROSCI.0406-13.2013

Lu, W.-Y., Man, H.-Y., Ju, W., Trimble, W. S., MacDonald, J. F., and Wang, Y. T. (2001). Activation of synaptic NMDA receptors induces membrane insertion of new AMPA receptors and LTP in cultured hippocampal neurons. Neuron 29, 243-254. doi: 10.1016/S0896-6273(01)00194-5

Malenka, R. C., and Bear, M. F. (2004). LTP and LTD: an embarrassment of riches. Neuron 44, 5-21. doi: 10.1016/j.neuron.2004.09.012

Maletic-Savatic, M., Malinow, R., and Svoboda, K. (1999). Rapid dendritic morphogenesis in CA1 hippocampal dendrites induced by synaptic activity. Science 283, 1923-1927. doi: 10.1126/science.283.5409.1923 
Markunas, C. A., Quinn, K. S., Collins, A. L., Garrett, M. E., Lachiewicz, A. M., Sommer, J. L., et al. (2010). Genetic variants in SLC9A9 are associated with measures of attention-deficit/hyperactivity disorder symptoms in families. Psychiatr. Genet. 20, 73-81. doi: 10.1097/YPG.0b013e3283351209

Masereel, B., Pochet, L., and Laeckmann, D. (2003). An overview of inhibitors of $\mathrm{Na}^{+} / \mathrm{H}^{+}$exchanger. Eur. J. Med. Chem. 38, 547-554. doi: 10.1016/S02235234(03)00100-4

Matsuzaki, M., Honkura, N., Ellis-Davies, G. C., and Kasai, H. (2004). Structural basis of long-term potentiation in single dendritic spines. Nature 429, 761-766. doi: $10.1038 /$ nature 02617

Maxfield, F. R., and Mcgraw, T. E. (2004). Endocytic recycling. Nat. Rev. Mol. Cell Biol. 5, 121-132. doi: 10.1038/nrm1315

Meda, S. A., Narayanan, B., Liu, J., Perrone-Bizzozero, N. I., Stevens, M. C., Calhoun, V. D., et al. (2012). A large scale multivariate parallel ICA method reveals novel imaging-genetic relationships for Alzheimer's disease in the ADNI cohort. Neuroimage 60, 1608-1621. doi: 10.1016/j.neuroimage.2011.12.076

Mick, E., Todorov, A., Smalley, S., Hu, X., Loo, S., Todd, R. D., et al. (2010). Family-based genome-wide association scan of attention-deficit/hyperactivity disorder. J. Am. Acad. Child Adolesc. Psychiatry 49, 898-905.e3. doi: 10.1016/j.jaac.2010.02.014

Mignot, C., Heron, D., Bursztyn, J., Momtchilova, M., Mayer, M., Whalen, S., et al. (2013). Novel mutation in SLC9A6 gene in a patient with Christianson syndrome and retinitis pigmentosum. Brain Dev. 35, 172-176. doi: 10.1016/j. braindev.2012.03.010

Morrow, E. M., Yoo, S. Y., Flavell, S. W., Kim, T. K., Lin, Y., Hill, R. S., et al. (2008). Identifying autism loci and genes by tracing recent shared ancestry. Science 321, 218-223. doi: 10.1126/science.1157657

Mott, D. D., Washburn, M. S., Zhang, S., and Dingledine, R. J. (2003). Subunitdependent modulation of kainate receptors by extracellular protons and polyamines. J. Neurosci. 23, 1179-1188.

Murphy, J. E., Padilla, B. E., Hasdemir, B., Cottrell, G. S., and Bunnett, N. W. (2009). Endosomes: a legitimate platform for the signaling train. Proc. Natl. Acad. Sci. U.S.A. 106, 17615-17622. doi: 10.1073/pnas.0906541106

Nachshen, D. A., and Drapeau, P. (1988). The regulation of cytosolic pH in isolated presynaptic nerve terminals from rat brain. J. Gen. Physiol. 91, 289-303. doi: 10.1085/jgp.91.2.289

Nakamura, N., Tanaka, S., Teko, Y., Mitsui, K., and Kanazawa, H. (2005). Four $\mathrm{Na}^{+} / \mathrm{H}^{+}$exchanger isoforms are distributed to golgi and post-golgi compartments and are involved in organelle $\mathrm{pH}$ regulation. J. Biol. Chem. 280, 1561-1572. doi: 10.1074/jbc.M410041200

Nazarewicz, R. R., Salazar, G., Patrushev, N., San Martin, A., Hilenski, L., Xiong, S., et al. (2011). Early endosomal antigen 1 (EEA1) is an obligate scaffold for angiotensin II-induced, PKC-alpha-dependent Akt activation in endosomes. J. Biol. Chem. 286, 2886-2895. doi: 10.1074/jbc.M110.141499

Nowak, L., Bregestovski, P., Ascher, P., Herbet, A., and Prochiantz, A. (1984). Magnesium gates glutamate-activated channels in mouse central neurones. Nature 307, 462-465. doi: 10.1038/307462a0

Numata, M., and Orlowski, J. (2001). Molecular cloning and characterization of a novel $\left(\mathrm{Na}^{+}, \mathrm{K}^{+}\right) / \mathrm{H}^{+}$exchanger localized to the trans-Golgi network. J. Biol. Chem. 276, 17387-17394. doi: 10.1074/jbc.M101319200

Ohgaki, R., Fukura, N., Matsushita, M., Mitsui, K., and Kanazawa, H. (2008). Cell surface levels of organellar $\mathrm{Na}^{+} / \mathrm{H}^{+}$exchanger isoform 6 are regulated by interaction with the receptor for activated C-kinase 1. J. Biol. Chem. 283, 4417-4429. doi: 10.1074/jbc.M705146200

Ohgaki, R., Matsushita, M., Kanazawa, H., Ogihara, S., Hoekstra, D., and van Ijzendoorn, S. C. (2010). The $\mathrm{Na}^{+} / \mathrm{H}^{+}$exchanger NHE6 in the endosomal recycling system is involved in the development of apical bile canalicular surface domains in HepG2 cells. Mol. Biol. Cell 21, 1293-1304. doi: 10.1091/mbc.E0909-0767

Ohgaki, R., Van, I. S. C., Matsushita, M., Hoekstra, D., and Kanazawa, H. (2011). Organellar $\mathrm{Na}^{+} / \mathrm{H}^{+}$exchangers: novel players in organelle $\mathrm{pH}$ regulation and their emerging functions. Biochemistry 50, 443-450. doi: 10.1021/bi101082e

Onishi, I., Lin, P. J., Numata, Y., Austin, P., Cipollone, J., Roberge, M., et al. (2012). Organellar $\left(\mathrm{Na}^{+}, \mathrm{K}^{+}\right) / \mathrm{H}^{+}$exchanger NHE7 regulates cell adhesion, invasion and anchorage-independent growth of breast cancer MDA-MB-231 cells. Oncol. Rep. 27, 311-317. doi: 10.3892/or.2011.1542

Orlowski, J., and Grinstein, S. (2004). Diversity of the mammalian sodium/proton exchanger SLC9 gene family. Pflugers Arch. 447, 549-565. doi: 10.1007/s00424003-1110-3
Orlowski, J., and Grinstein, S. (2007). Emerging roles of alkali cation/proton exchangers in organellar homeostasis. Curr. Opin. Cell Biol. 19, 483-492. doi: 10.1016/j.ceb.2007.06.001

Ouyang, Q., Lizarraga, S. B., Schmidt, M., Yang, U., Gong, J., Ellisor, D., et al. (2013). Christianson syndrome protein nhe6 modulates trkb endosomal signaling required for neuronal circuit development. Neuron. doi: 10.1016/j.neuron.2013.07.043

Park, M., Salgado, J. M., Ostroff, L., Helton, T. D., Robinson, C. G., Harris, K. M., et al. (2006). Plasticity-induced growth of dendritic spines by exocytic trafficking from recycling endosomes. Neuron 52, 817-830. doi: 10.1016/j.neuron.2006.09.040

Platta, H. W., and Stenmark, H. (2011). Endocytosis and signaling. Curr. Opin. Cell Biol. 23, 393-403. doi: 10.1016/j.ceb.2011.03.008

Raley-Susman, K. M., Cragoe, E. J. Jr., Sapolsky, R. M., and Kopito, R. R. (1991). Regulation of intracellular $\mathrm{pH}$ in cultured hippocampal neurons by an amiloride-insensitive $\mathrm{Na}^{+} / \mathrm{H}^{+}$exchanger. J. Biol. Chem. 266, 2739-2745.

Rocha, M. A., Crockett, D. P., Wong, L. Y., Richardson, J. R., and Sonsalla, P. K. (2008). $\mathrm{Na}^{+} / \mathrm{H}^{+}$exchanger inhibition modifies dopamine neurotransmission during normal and metabolic stress conditions. J. Neurochem. 106, 231-243. doi: 10.1111/j.1471-4159.2008.05355.x

Ronicke, R., Schroder, U. H., Bohm, K., and Reymann, K. G. (2009). The $\mathrm{Na}^{+} / \mathrm{H}^{+}$ exchanger modulates long-term potentiation in rat hippocampal slices. Naunyn Schmiedebergs Arch. Pharmacol. 379, 233-239. doi: 10.1007/s00210-0080364-x

Sauvaigo, S., Vigne, P., Frelin, C., and Lazdunski, M. (1984). Identification of an amiloride sensitive $\mathrm{Na}^{+} / \mathrm{H}^{+}$exchange system in brain synaptosomes. Brain Res. 301, 371-374. doi: 10.1016/0006-8993(84)91106-5

Schenck, A., Goto-Silva, L., Collinet, C., Rhinn, M., Giner, A., Habermann, B., et al. (2008). The endosomal protein Appll mediates Akt substrate specificity and cell survival in vertebrate development. Cell 133, 486-497. doi: 10.1016/j.cell.2008.02.044

Schroer, R. J., Holden, K. R., Tarpey, P. S., Matheus, M. G., Griesemer, D. A., Friez, M. J., et al. (2010). Natural history of Christianson syndrome. Am. J. Med. Genet. A 152A, 2775-2783. doi: 10.1002/ajmg.a.33093

Schuchmann, S., Schmitz, D., Rivera, C., Vanhatalo, S., Salmen, B., Mackie, K., et al. (2006). Experimental febrile seizures are precipitated by a hyperthermiainduced respiratory alkalosis. Nat. Med. 12, 817-823. doi: 10.1038/nm1422

Schwiening, C. J., and Boron, W. F. (1994). Regulation of intracellular pH in pyramidal neurones from the rat hippocampus by $\mathrm{Na}^{+}$-dependent $\mathrm{Cl}^{-}-\mathrm{HCO}^{3-}$ exchange. J. Physiol. 475, 59-67.

Scita, G., and Di Fiore, P. P. (2010). The endocytic matrix. Nature 463, 464-473. doi: $10.1038 /$ nature 08910

Scott, C. C., and Gruenberg, J. (2011). Ion flux and the function of endosomes and lysosomes: $\mathrm{pH}$ is just the start: the flux of ions across endosomal membranes influences endosome function not only through regulation of the luminal $\mathrm{pH}$. Bioessays 33, 103-110. doi: 10.1002/bies.201000108

Shepherd, J. D., and Huganir, R. L. (2007). The cell biology of synaptic plasticity: AMPA receptor trafficking. Annu. Rev. Cell Dev. Biol. 23, 613-643. doi: 10.1146/annurev.cellbio.23.090506.123516

Slepkov, E. R., Rainey, J. K., Sykes, B. D., and Fliegel, L. (2007). Structural and functional analysis of the $\mathrm{Na}^{+} / \mathrm{H}^{+}$exchanger. Biochem. J. 401, 623-633. doi 10.1042/BJ20061062

Somjen, G. G. (1984). Acidification of interstitial fluid in hippocampal formation caused by seizures and by spreading depression. Brain Res. 311, 186-188. doi: 10.1016/0006-8993(84)91416-1

Sorkin, A., and von Zastrow, M. (2009). Endocytosis and signalling: intertwining molecular networks. Nat. Rev. Mol. Cell Biol. 10, 609-622. doi: $10.1038 / \mathrm{nrm} 2748$

Stauber, T., and Jentsch, T. J. (2013). Chloride in vesicular trafficking and function. Annu. Rev. Physiol. 75, 453-477. doi: 10.1146/annurev-physiol-030212-183702

Szabo, E. Z., Numata, M., Shull, G. E., and Orlowski, J. (2000). Kinetic and pharmacological properties of human brain $\mathrm{Na}^{+} / \mathrm{H}^{+}$exchanger isoform 5 stably expressed in Chinese hamster ovary cells. J. Biol. Chem. 275, 6302-6307. doi: 10.1074/jbc.275.9.6302

Takahashi, Y., Hosoki, K., Matsushita, M., Funatsuka, M., Saito, K., Kanazawa, H., et al. (2011). A loss-of-function mutation in the SLC9A6 gene causes X-linked mental retardation resembling Angelman syndrome. Am. J. Med. Genet. B Neuropsychiatr. Genet. 156B, 799-807. doi: 10.1002/ajmg. b. 31221 
Tang, C. M., Dichter, M., and Morad, M. (1990). Modulation of the N-methylD-aspartate channel by extracellular $\mathrm{H}^{+}$. Proc. Natl. Acad. Sci. U.S.A. 87, 6445-6449. doi: 10.1073/pnas.87.16.6445

Traynelis, S. F., and Cull-Candy, S. G. (1990). Proton inhibition of N-methylD-aspartate receptors in cerebellar neurons. Nature 345, 347-350. doi: $10.1038 / 345347 \mathrm{a} 0$

Trudeau, L. E., Parpura, V., and Haydon, P. G. (1999). Activation of neurotransmitter release in hippocampal nerve terminals during recovery from intracellular acidification. J. Neurophysiol. 81, 2627-2635.

Vaegter, C. B., Jansen, P., Fjorback, A. W., Glerup, S., Skeldal, S., Kjolby, M., et al. (2011). Sortilin associates with Trk receptors to enhance anterograde transport and neurotrophin signaling. Nat. Neurosci. 14, 54-61. doi: 10.1038/ nn. 2689

Varsano, T., Dong, M. Q., Niesman, I., Gacula, H., Lou, X., Ma, T., et al. (2006). GIPC is recruited by APPL to peripheral TrkA endosomes and regulates TrkA trafficking and signaling. Mol. Cell Biol. 26, 8942-8952. doi: 10.1128/MCB.00305-06

Velisek, L. (1998). Extracellular acidosis and high levels of carbon dioxide suppress synaptic transmission and prevent the induction of long-term potentiation in the CA1 region of rat hippocampal slices. Hippocampus 8, 24-32. doi: 10.1002/ (SICI) 1098-1063(1998)8:1<24::AID-HIPO3>3.0.CO;2-7

Velisek, L., Dreier, J. P., Stanton, P. K., Heinemann, U., and Moshe, S. L. (1994). Lowering of extracellular $\mathrm{pH}$ suppresses low- $\mathrm{Mg}^{2+}$-induces seizures in combined entorhinal cortex-hippocampal slices. Exp. Brain Res. 101, 44-52. doi: 10.1007/BF00243215

Wakabayashi, S., Shigekawa, M., and Pouyssegur, J. (1997). Molecular physiology of vertebrate $\mathrm{Na}^{+} / \mathrm{H}^{+}$exchangers. Physiol. Rev. 77, 51-74.

Walz, H. A., Shi, X., Chouinard, M., Bue, C. A., Navaroli, D. M., Hayakawa, A., et al. (2010). Isoform-specific regulation of Akt signaling by the endosomal protein WDFY2. J. Biol. Chem. 285, 14101-14108. doi: 10.1074/jbc.M110. 110536

Wang, Z., Edwards, J. G., Riley, N., Provance, D. W. Jr., Karcher, R., Li, X. D., et al. (2008). Myosin Vb mobilizes recycling endosomes and AMPA receptors for postsynaptic plasticity. Cell 135, 535-548. doi: 10.1016/j.cell.2008.09.057
Wemmie, J. A., Zha, X.-M., and Welsh, M. J. (2008). "Acid-sensing ion channels (ASICs) and pH in synapse physiology," in Structural and Functional Organization of the Synapse, eds J. W. Hell and M. D. Ehlers (Philadelphia, PA: Springer), 661-681.

Xinhan, L., Matsushita, M., Numaza, M., Taguchi, A., Mitsui, K., and Kanazawa, H. (2011). $\mathrm{Na}^{+} / \mathrm{H}^{+}$exchanger isoform 6 (NHE6/SLC9A6) is involved in clathrin-dependent endocytosis of transferrin. Am. J. Physiol. Cell Physiol. 301, C1431-C1444. doi: 10.1152/ajpcell.00154.2011

Zha, X. M. (2013). Acid-sensing ion channels: trafficking and synaptic function. Mol. Brain 6, 1. doi: 10.1186/1756-6606-6-1

Zha, X. M., Wemmie, J. A., Green, S. H., and Welsh, M. J. (2006). Acidsensing ion channel $1 \mathrm{a}$ is a postsynaptic proton receptor that affects the density of dendritic spines. Proc. Natl. Acad. Sci. U.S.A. 103, 16556-16561. doi: 10.1073/pnas.0608018103

Zhou, Q., and Sheng, M. (2013). NMDA receptors in nervous system diseases. Neuropharmacology 74, 69-75. doi: 10.1016/j.neuropharm.2013.03.030

Conflict of Interest Statement: The authors declare that the research was conducted in the absence of any commercial or financial relationships that could be construed as a potential conflict of interest.

Received: 01 October 2013; paper pending published: 18 October 2013; accepted: 27 December 2013; published online: 13 January 2014.

Citation: Diering GH and Numata $M$ (2014) Endosomal pH in neuronal signaling and synaptic transmission: role of $\mathrm{Na}^{+} / \mathrm{H}^{+}$exchanger NHE5. Front. Physiol. 4:412. doi: 10.3389/fphys.2013.00412

This article was submitted to Membrane Physiology and Membrane Biophysics, a section of the journal Frontiers in Physiology.

Copyright (c) 2014 Diering and Numata. This is an open-access article distributed under the terms of the Creative Commons Attribution License (CC BY). The use, distribution or reproduction in other forums is permitted, provided the original author(s) or licensor are credited and that the original publication in this journal is cited, in accordance with accepted academic practice. No use, distribution or reproduction is permitted which does not comply with these terms. 